\title{
INVESTIGATING THE EFFECT OF COVID-19 GLOBAL TRAVEL RESTRICTIONS ON TOURISTS' TRAVEL BEHAVIOR, HABITS AND INTENTIONS “APPLIED STUDY ON SAUDI TOURISTS"
}

\author{
Sameh A. REFAAT ${ }^{*}$ \\ King Saud University, Department of Tourism and Hotel Management, \\ College of Tourism and Archeology, Saudi Arabia, e-mail: samehtourism2013@outlook.com
}

Hossam F. ARAFA

The Higher Institute of Tourism and Hotels, (EGOTH),

Department of Tourism Studies, Luxor, Egypt, e-mail: hossamarafa1977@gmail.com

\begin{abstract}
Citation: Refaat, S.A., \& Arafa, H.F. (2022). INVESTIGATING THE EFFECT OF COVID-19 GLOBAL TRAVEL RESTRICTIONS ON TOURISTS' TRAVEL BEHAVIOR, HABITS AND INTENTIONS "APPLIED STUDY ON SAUDI TOURISTS”. GeoJournal of Tourism and Geosites, 40(1), 49-55. https://doi.org/10.30892/gtg.40105-801
\end{abstract}

\begin{abstract}
Covid-19 pandemic posed new global restrictions affected movement and tourists' travel behavior and habits. This study aims to investigate and monitor these effects to understand the new features of tourists' behavior in general and Saudis in particular. The study depending on closed-ended questionnaire directed to 374 Saudi air travelers to investigate their travel habits and behavior before and after the pandemic, using t-test and chi- square to analyze it. The study resulted that covid-19 travel restrictions affected travelers' preferences, habits and intentions, especially concerning destination choice, reservation methods, tourist activities, and means of transportation, accommodation and trip duration.
\end{abstract}

Key words: travel restrictions, covid-19, travelers, behaviors, habits, tourism

$* * * * *$

\section{INTRODUCTION}

"In April 2020, 100\% of the world's tourist destinations have imposed travel restrictions in response to the COVID19 pandemic. The World Tourism Organization (UNWTO) has predicted that the number of international tourists will fall by up to $80 \%$ this year. An estimated 120 million tourism jobs will be at risk" (UNWTO, 2020b). According to Seyfia et al. (2020) in an effort to contain the advancement of the novel coronavirus (COVID-19) pandemic, many states have introduced unprecedented peacetime measures ranging from border closures and travel bans to the suspension of visa exemptions, as well as internal mobility restrictions, including full lockdowns and quarantine for incoming passengers. Covid-19, the pandemic is changing individuals' behavior. Worldwide, the restrictions put in place to limit the diffusion and impacts of Covid-19 have had a widespread impact on people's lives in general, and in travel and tourism in particular (Haque, 2020). The world's governments have taken a number of measures to mitigate the direct effects on the tourism sector, although it is expected that this pandemic will change the shape of the travel and tourism sector in the future, especially with regard to health safety (Kampel, 2020). This study aims to monitor and analyze the effects of the closure wave and global restrictions on movement and mobility imposed by the Covid 19 pandemic on the change in the behavior and travel habits of tourists, and the study focuses on Saudi tourists in particular, especially with partial decisions to open airports and allow travel according to specific terms and conditions.

\section{LITREATURE REVIEW}

\section{Travel and Tourism in the Corona Virus Era}

Jamal and Budke (2020) state that "the travel and tourism industry is one of the largest in the world, with globalization, threats and challenges have magnified with the ease of travel and the rapid movement of goods, knowledge, finance and disease". However, Deb and Nafi (2020) mention that health issues and climate change have become the biggest challenges for the tourism industry, and now the Corona pandemic, which began in the Chinese province of Hubei quickly, has spread to the rest of the world, threatening a global economic recession. Gallo et al., 2021: 1033 explain that "there is no doubt that the current period is very difficult for business and economic development. The current outbreak of the disease has had dire economic consequences around the world. It is a period that requires major changes so that markets can recover in general after the pandemic. It will depend largely on the quality of decisions at the state and institutional level, which is an opportunity to learn from the crisis and develop future scenarios". Deb and Nafi (2020) point out that the tourism industry is facing a crisis and exceptional challenge that has not happened before, as hotels and resorts have been closed and travel agencies and airline companies have been suspended due to the health conditions affected by the COVID-19 pandemic (Orlik et al., 2020). "In the past years, the tourism industry has witnessed a remarkable growth in the number of tourists around the world and in tourism revenues. With

\footnotetext{
* Corresponding author
} 
international tourist arrivals increasing $4 \%$ to become 1.5 billion globally in 2019, experts had been expecting 2020 to be another successful year for tourism until the scenario changed with the coronavirus outbreak" (Bakar and Rosbi, 2020).

At the end of 2020, according to UNWTO Barometer, December 2020: 1 "International tourist arrivals fell by average $72 \%$ in January-October 2020 over the same period last year, curbed by slow virus containment, low traveler confidence and important restrictions on travel still in place, due to the COVID-19 pandemic". The COVID-19 pandemic has severely affected the economic development of all countries of the world, even the economies of the most developed countries such as the USA, UK, Japan and Europe (Kumudumali, 2020). Since there is a basic and direct relationship between pandemics and travel, tourists might cancel their trips and avoid travel (Sultana et al. 2020).

\section{Air Transport and the Ramifications of Covid-19}

Sheard (2014) states that Air transport including airports and aircraft manufacturing is closely related and considered as a major catalyst for other economic activities, especially the tourism industry. OECD (2020): 2 adds that "flights to a large number of destinations are an essential factor in international tourism", according to the Centers for Disease Control and Prevention (2020): 1 "The COVID-19 outbreak represents the first global pandemic to affect passenger air transport, which began in the late 1950s. The infamous 1918 influenza pandemic and others had little impact on commercial air travel, where international air travel was not as extensive as it is today". Elias (2020) displays that the COVID-19 pandemic has had a major impact on civil aviation with more stay-at-home travel restrictions and quarantine after travel from certain regions. These public concerns have led to a significant drop in demand for air travel since March 2020. Expectations indicate that passenger air travel will not return to normal levels until 2023. A significant decrease in the demand for passenger air transport threatens the existence of a large number of companies in various sectors of the air transport industry and threatens the survival of many jobs (OECD, 2020). According to ICAO report (2021): 5, 6, 11 "Estimated impact of COVID-19 on global scheduled travel for 2020 compared to 2019: A 50\% decrease in airline seats, and a 60\% decrease in the number of passengers". Moreover, there is " $54 \%$ global decrease in passenger demand, - $40 \%$ in global passenger capacity and $-84.3 \mathrm{~b} \$$ in global net profit for air lines companies". As evidenced by the field interviews managed by Sanchez et.al (2020) during and after the pandemic, whatever the type of flight, traveler confidence will decline due to health circumstances and lower income levels for individuals due to the economic crisis will reduce the demand for air travel. Airlines will need difficult recovery plans to return safely and securely to business again. "The resumption of international flights requires global cooperation, consultations, and coordination of policies and risk management measures required between governments to support the opening of the skies" (Rooley, 2020: 2).

\section{Travel \&Tourism Movement and International Travel Restrictions}

Camitz and Liljeros (2006) begin that when pandemics occur, at the beginning of pandemics, travel and movement restrictions are always important to monitor the speed of transmission of the pandemic between geographical areas, so that effective ways to confront it can be identified. Quilty et al. (2020) add that some countries have also put travel restrictions and quarantines to prevent the spread of infection, so preventing infected travelers from transmitting stops additional chains of transmission. And if it does not prevent the spread of the epidemic, it will at least delay its spread in other regions. Since its detection in China in December 2019, the novel coronavirus (COVID-19) has spread swiftly around world. As of August 23, 2020, more than twenty-three million people have been infected and over 800,000 deaths have been reported by World Health Organization (WHO, 2020). Numerous countries have adopted measures unprecedented since the end of the Second World War to contain the advancement of the virus and to reduce the number of cases and deaths. Seyfia et al. (2020) report that many countries and regions have implemented strict border controls and severe restrictions on international travel, including restrictions on tourism-related motilities extended the suspension of inbound travel for all foreigners to mitigate Corona pandemic transmission. The profound disruption to travel and trade has threatened the survival of many travel agencies, airlines and allied sectors, with huge negative economic and social impacts (Petersen et al. 2020). Since the World Health Organization declared a global health emergency on January 2020, about 180 countries have put in place a number of health restrictions that have mainly disrupted international travel, including entry bans, visa restrictions and quarantine for arrivals (WHO, 2020).

In this context, Niestad (2020) declares that the EU countries began to ease their travel bans from $1^{\text {st }}$ July 2020 that had been introduced in response to the crisis to give a much-needed boost to virus-ravaged economies (e.g. Italy, Spain, France) and in particular the tourism sector. According to (Deloitte, 2020), although some European countries where the first wave of the pandemic was under control began lifting COVID-19 restrictions (e.g. France, Austria) in early June, some other countries which were still greatly affected and in which the death toll from the coronavirus was rising at an unacceptable rate (e.g. Brazil), extended the suspension of inbound travel for all foreigners to mitigate the spread of COVID-19. Some other countries outlined strict new travel restrictions and introduced a 14-day mandatory quarantine on arriving travelers (e.g. UK) in an effort to prevent a second wave of the virus. However, such measures may also be met by reciprocal responses. Nevertheless, the enforcement of quarantine on international travelers clearly has implications for the relative attractiveness of countries to tourists after lockdowns have been eased (Seyfia et al. 2020).

In the case of tourism, Budiasa and Nadra (2016) explain that Globalization has contributed to the boom in tourism, with the expansion of reservations and all tourism business, and the emergence of comprehensive tourism programs, airline tickets and low-cost hotel rooms via the Internet, which led to attracting people to travel significantly. However, Adams (2014) explains that however, the phenomenon of globalization, despite its positives, also brings us some threats to the security, safety and welfare of the societies of the world that has become intertwined, such as warnings and travel 
restrictions to confront global pandemics, and they will remain in our view, despite their importance, unfair measures that cause a lot of harm. According to UNWTO seventh reports till first of September 2020: 1, 3 " 115 (53\% of all tourist destinations globally) have relaxed international travel restrictions. This represents an increase of 28 destinations compared to July 19, 2020. Also, 93 destinations (43\% of all global destinations) keep their borders completely closed to international tourism. This is a decrease of 22 destinations compared to July 19, 2020". Moreover, "the eighth report of the UNWTO in December 2020: 1, 5 shows that a total of 152 tourist destinations have eased restrictions on international tourism, up from 115 on September 1. Meanwhile, 59 destinations kept their borders closed to tourists, a drop of 34 over the same two-month period", it is normal for destinations that have low indicators in health, hygiene and environmental performance tending to keep its borders closed. According to UNWTO Secretary-General Pololikashvili (2020), lifting travel restrictions are essential for the tourism industry to recover from the social and economic impacts of the pandemic. Governments play an important role to work together to lift restrictions once it is safe to do so.

\section{The Effects of International Travel Restrictions on Traveler's Behavior, habits and intentions}

Haque (2020) shows that Covid-19 pandemic has changed individuals 'behavior, worldwide the restrictions put in place to limit the diffusion and impacts of Covid-19 have had a widespread impact on people's lives. According to different researches, there are three stages of consumer behavior: panic, adapt and new normal. According to Shi et al. (2019) at the early stage (panic), different governments-imposed restrictions along with fears of contracting and spreading the virus, such as reducing the using of mass transport modes, increased amount of working from home, e-learning, and a reduced number of public activities and events results in travel demand drop at highest rate. Under the (adapt) stage, people are changing their day to day behavior: they might be more inclined to perform activities at home, work from home and avoid crowd, and also changing behavior in travel mode choice. People might also be more interested to get home delivery of goods purchased online (e.g., food, clothes, accessories, groceries) which resulting in fewer shopping trips. The decreased level of individual mobility is not the only impact, though. People in general are increasingly adapting their daily behavior as lockdowns are prolonged. In the third stage (new normal), people have a new focus on the home as a place of stability and safety in the current deeply uncertain economic landscape. People are focusing their spending on in-home comfort and entertainment such as food preparation products. No doubt these behavioral changes decreasing the catchment area they travel around, spending more time in their local neighborhood or fostering local neighborhood trips which could be the 'new normal' for cities in the long run (Haque, 2020). Puttaiah (2020) displays the main question in minds nowadays, will these changes in behavior last after COVID-19 subsides, or will people (consumers or travelers') old habits die hard? All consumer behavior has strong location and time dependencies. Behavior can differ significantly from one location to another depending on cultures, geographies, etc. The pandemic is making this dimension of behavior more complex; for example, since physical movement is restricted, people are migrating into virtual worlds at an unprecedented rate and are exposed to newer influences. This could require us to go beyond traditional methods of modeling their behavior.

Moreover, Puttaiah (2020) argues that behavior and habit changes are also directly linked to the extent of exposure to new environments. Research shows that it can take between "18 and 254 days to form a new habit; on average it takes about 66 days". People more quickly adopt habits that do not significantly change existing routines. Today, people are settling into new patterns of behavior for considerable lengths of time in response to the multiple waves of this pandemic. This is fertile ground for new habit formation especially in travel and tourism, the future of the global tourism industry will certainly be affected by the residual impacts of the pandemic, and for a while there will be a possible relationship between (expected or perceived risks) and (travel intentions) of tourists after the Corona crisis. In light of the fact that Covid-19 is considered the largest global health crisis affecting tourism in the modern era, the impact of these crises on the behavior of tourists does not have clear evidence or previous experiences of results (Matiza, 2020). However, it is certain in tourism that the expected risks in the mind of the tourist are related to his inclinations and decisions towards travel and tourism (Adam, 2015). Research that has examined the impact of perceived risks in tourism indicates that they are multidimensional and include, for example: food safety, weather, social, psychological, financial and service quality risks, and inevitably influence tourist decision-making (Cui et al., 2016). In another view, "the perceived risks in the tourism sector are also multi-dimensional: but may reach 11 risks, including: financial risks, health risks, psychological risks, social risks, crimes, terrorism and political risks" (Matiza and Slabbert, 2021: 581). Matiza (2020): 3 focus that in the context of Covid-19 crises, "three risk typologies can be specified: (Health), (Psychological) and (Social) risks that will be the most influential on tourists' travel decisions in the near future after the COVID-19 pandemic". In addition, it can be seen that travel and tourism risk refusal is higher when tourists consider international tourism compared to domestic tourism, this is referred to as (the bias for the homeland as it is safer than the outside) (Wolff et al., 2019). Puttaiah (2020) points out that the expected emerging changes in consumer behavior in general and in tourists and travelers' behaviors in particular during and after Covid-19 crises will be as following:

- "Increased digital adoption: people shifting to digital platforms for day-to-day needs" Puttaiah (2020): 2

- "Change in mobility patterns: less use of public transport, more remote working etc.," Puttaiah (2020): 2 and greater tendency for domestic tourism hoping for fewer travel restrictions and less safety risks.

- Advanced priority of health and safety: before, during and after travel and tourism different decisions, interpersonal behavior, social distancing, wearing masks, increased hygiene, healthy eating etc.

Habits, preferences and behavior of Saudi Outbound tourists before and after covid-19 pandemic

Outbound travel from the Middle East has grown remarkably from 30 million tourists in 2008 to about 41 million tourists in 2018 with an average annual growth rate 3\% (UNWTO Tourism Dashboard, 2021). Saudi Arabia was the 
Middle East's largest source market for international tourism (Ayeh, 2017). The number of outbound tourists generated by the country grew from 4.1 million in 2008 (UNWTO Tourism Dashboard, 2021), to over 27 million in 2019 (UNWTO, 2020 a), spending more than $\$ 15$ billion (UNWTO Tourism Dashboard, 2021). According to Picodi.com analytic survey report (2016) which was conducted on June 2019 on Saudis to investigate the habits and preferences of Saudi travelers before covid-19 pandemic, the majority of Saudis used to prefer going abroad over domestic travels, the most preferred countries to visit were the UAE, Bahrain, Jordan, Singapore, Malaysia, Azerbaijan, Georgia, Austria, Germany, Switzerland, Australia and Los Angeles. However, other destinations which used to be highly preferred by most Saudis like Egypt and Lebanon, lost their attractiveness because of economic and security instability after the Arab spring revolutions in 2011 (AL-Feky, 2016). According to figures in Picodi.com (2019) "Time to Relax, Analytic report" about habits and preferences of Saudi travelers before covid-19 pandemic, the majority of Saudi travelers prefer to organize their trips by themselves and in advance (63 to 73\%), travel with families in shoulder and low seasons, travel for sightseeing and beach vacations, visit new places, use taxies and private cars, and trying destinations local food. An average Saudi spends \$794 per person on a holiday, which places Saudi Arabia in the top ten vacation spending nationalities.

Because of the wide spread of corona virus, the Saudi authorities announced an official prevention for citizens and residences from travelling abroad and posed very tight restrictions on the international travelling movement from and to the country from the first quarter of 2020 till 17 may 2021. This long period of travel prevention and travel restrictions affected Saudi travelers' traveling behavior, preferences, habits and intentions.

The official statistics announced by the Saudi ministry of interior after two days of the validity of the official permit to Saudi citizens to travel abroad (17 and 18 may 2021), stated that the majority of travelers from different Saudi land, sea and air ports preferred to travel to a domestic or regional destination compared to long distance destinations. The first five preferred destinations for Saudi air travelers are UAE (1938), Egypt (1545), Qatar (299), USA (233) and UK (165) (Saudi ministry of interior, 2021). Hany Al-Omairy (member of the Saudi society of travel and tourism) stated that the official permit of travelling and reducing travel restrictions refreshed travel agencies business by $30 \%$, and stimulated demand for visiting relatives, business and honeymoon trips. As well he claimed that a big party of Saudi travelers prefers to communicate travel agencies to ask about travel conditions and procedures and organize their future trips, while another party prefers to delay their vacation arrangements until travel restrictions are totally removed. Moreover, he stated that despite there is a greater preference for domestic destinations after the validity of the travel permit, the most preferred destinations for Saudi tourists are UAE, Bahrain, Egypt, Indonesia, Georgia and Ukraine (Alarabiya.net, 2021).

\section{METHODS AND MATERIALS}

The research was conducted using a questionnaire to assess the effect of Covid-19 global travel restrictions on tourists' travel behavior, habits and intentions, distributed to Saudi travelers who are travelling from Jeddah and El-Riyadh international airports to spend their vacations abroad. The study was conducted on the first two days of the validity of the official permit to Saudi citizens to travel abroad (17 may and 18 may 2021), after an approximately one year and 4 months of official prevention of travelling abroad due to covid-19 pandemic. Five points Likert scale was used ranging from (1) strongly disagree, (2) disagree, (3) may be, (4) agree, and (5) strongly agree. The method relies on data collection on a questionnaire via e-mail or in person by the researchers. The collected questionnaires were processed and analyzed statistically using SPSS v20.
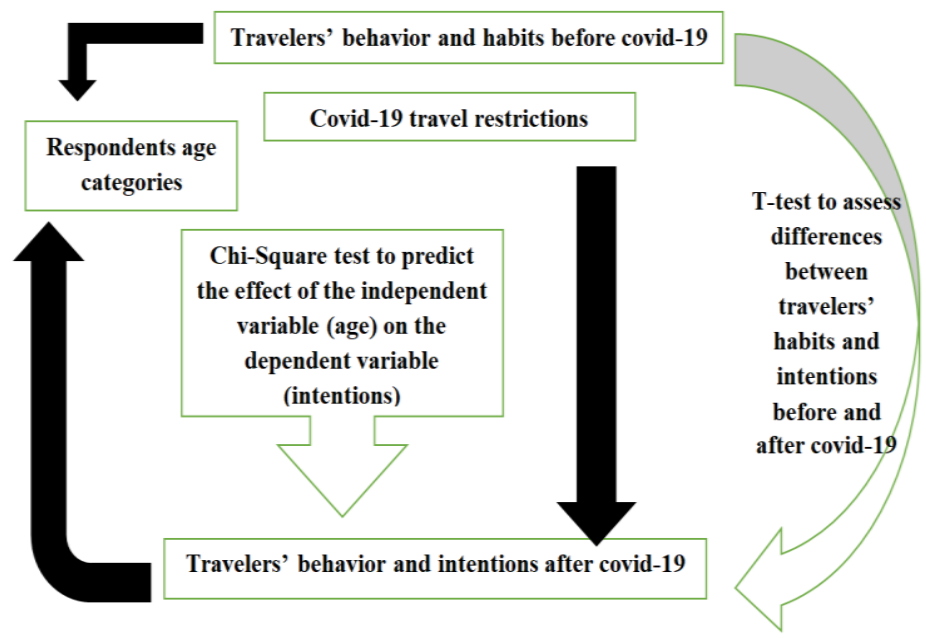

Figure 1. Research methods

\section{A. Research Measures}

The research comprised three phases. The first phase includes the demographic data of the respondents, the second phase displays respondents' travelling habits and behavior pre covid-19 pandemic, while the third phase investigates respondents' travelling habits, behavior and intentions post covid-19 pandemic.

\section{B. Sample Selection}

The study was conducted on a purposive sample of Saudi citizens or who were travelling abroad to spend a vacation, to investigate their travelling habits and behavior pre covid-19 and post covid-19 pandemic, and clarify and analyze the differences and changes in travel behavior due to the new permanent travel restrictions related to the pandemic. The study was conducted on a sample of 450 travelers from 4735 travelers by air on the first two days of the validity of the official permit of travelling abroad (Saudi ministry of interior, alarabiya.net 20 may 2021), having 374 valid and accurate forms.

\section{Discussion and Data Analysis}

The researchers use both descriptive and inferential statistics to test and determine the effect of covid-19 travel restrictions on travelers' habits, behavior, preferences and intentions while travelling for a vacation. Mean scores, standard deviations are calculated for all factors in the research. Chi-Square at a significance level of 5\% is used to find 
relationships to predict the effect of the independent variable (age) on the dependent variable (traveler intentions), As well T-test at a significance level of $5 \%$ is used to assess differences between travelers habits before and after covid-19. The collected data were analyzed using the statistical package for social science (SPSS v 20). Figure 2 shows that the study was conducted on three age groups of Saudi travelers (18-30), (31-50), and (50<).

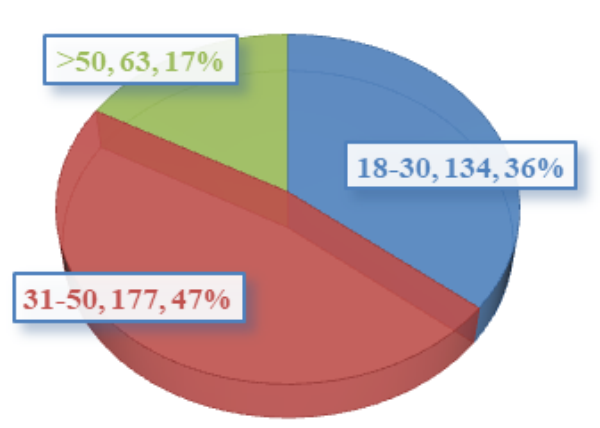

Figure 2. Respondents Age Categories

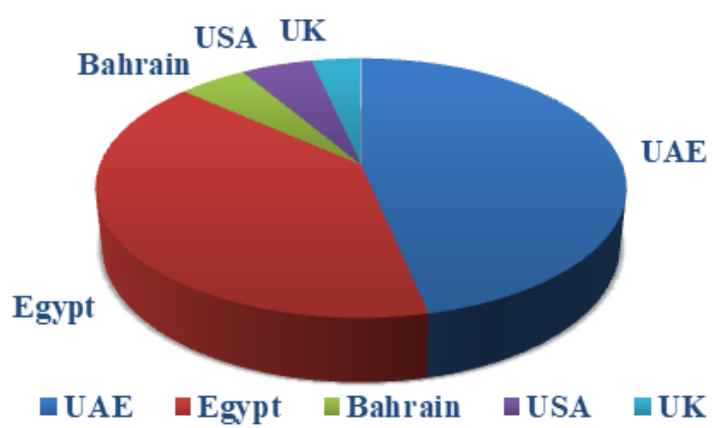

Figure 3. Respondents top visited destinations after the official travel permit (Saudi Ministry of Interior decisions 2021)

Table 1. Saudi travelers' preferred destination type and travel companions before Covid-19 travel restrictions (by age group)

\begin{tabular}{|c|c|c|c|c|c|c|c|}
\hline \multirow{2}{*}{ Age group } & \multirow{2}{*}{ Total } & \multicolumn{3}{|c|}{ Preferred travel companions } & \multicolumn{3}{c|}{ Preferred type of destinations } \\
\cline { 3 - 7 } & & Family & Friends & Ethical groups & Domestic & Regional & International \\
\hline $18-30$ & 134 & 15 & 97 & 22 & 23 & 36 & 75 \\
\hline$\%$ & 35.83 & 11.19 & 72.39 & 16.42 & 17.16 & 26.87 & 55.97 \\
\hline $31-50$ & 177 & 154 & 21 & 2 & 36 & 71 & 70 \\
\hline$\%$ & 47.33 & 87.01 & 11.86 & 1.13 & 20.34 & 40.11 & 39.55 \\
\hline $50<$ & 63 & 21 & 30 & 12 & 12 & 22 & 29 \\
\hline$\%$ & 16.84 & 33.33 & 47.62 & 19.05 & 19.05 & 34.92 & 46.03 \\
\hline Total & 374 & 190 & 148 & 36 & 71 & 129 & 174 \\
\hline$\%$ & 100 & 50.8 & 39.57 & 9.36 & 18.98 & 34.5 & 46.52 \\
\hline
\end{tabular}

The previous Table 2 shows that Saudi travelers aged (18-30) and $(50<)$ used to prefer more international trips $(55.97 \%),(46.03 \%)$ with friends $(72.39 \%),(47.62 \%)$ in consecutively, while respondents aged (31-50) preferred regional trips $(40.11 \%)$ with their families $(87.01 \%)$. In general, respondents preferred more international trips $(46.52 \%)$ accompanied by family $(50.8 \%)$. Figure 3 shows that the top five visited destination after the official travel permit (Saudi Ministry of Interior decisions 2021) are UAE (170) respondent, Egypt (145), USA (19), Bahrain (18) and UK (13). So, the majority preferred to travel to regional destinations in comparison to whom preferred to travel to international long distance destinations, which is opposite to what they used to prefer before the pandemic as shown in table (2), meaning that travel preferences, habits and intentions are affected by covid-19 travel restrictions.

Table 2. The relationship between travelers' age and their travel intentions Chi-Square Tests a. 0 cells $(.0 \%)$ have expected count less than 5 . The minimum expected count is

\begin{tabular}{|l|c|c|c|}
\hline \multicolumn{1}{|c}{140.71} \\
\hline Pearson Chi-Square & $330.674^{\mathrm{a}}$ & 8 & .000 \\
\hline Likelihood Ratio & 346.315 & 8 & .000 \\
\hline Linear-by-Linear Association & 39.570 & 1 & .000 \\
\hline N of Valid Cases & 5973 & & \\
\hline
\end{tabular}

\section{Inferential statistic \\ The relationship between travelers' age and their travel intentions}

The table shows that $\mathrm{P}$. value of $\mathrm{ch}^{2}=(330.674)$ with significant level less than $0.05=(0.000)$. It indicates that the variables are not independent and there is a strong statistical relationship between the variable (age of traveler) and the variable (the travel's intention), which means that travelers' travel intentions and preferences differ according to their ages.

Table 3. Mean, S. Deviation and Acceptance degree of Saudi Tourists' traveling preferences, habits and intentions before and after covid-19 pandemic

\begin{tabular}{|l|c|c|c|c|c|c|}
\hline \multicolumn{1}{|c|}{ Statements } & \multicolumn{3}{c|}{ Before covid-19 } & \multicolumn{3}{c|}{ After Covid-19 } \\
\cline { 2 - 8 } & mean & S-deviation & Acceptance level & mean & S-Deviation & Acceptance level \\
\hline 1-I prefer to travel in groups. & 3.4 & .914 & Agree & 2.73 & 1.115 & Maybe \\
\hline 2-I prefer to travel by plane and slightly by car. & 3.48 & 1.242 & Agree & 2.51 & 1.153 & Disagree \\
\hline $\begin{array}{l}\text { 3-Health and safety have the first priority concern before price, } \\
\text { accessibility and service quality. }\end{array}$ & 1.82 & .693 & S. Disagree & 4.30 & .799 & S. Agree \\
\hline 4-I always prefer to visit crowded places & 3.50 & 1.303 & Agree & 2.71 & 1.374 & Maybe \\
\hline 5-I prefer international trips than domestic trips. & 3.19 & 1.393 & Maybe & 3.3 & 1.308 & Maybe \\
\hline $\begin{array}{l}\text { 6-I depend on digital channels when planning and booking a trip } \\
\text { instead of visiting a travel agent. }\end{array}$ & 4.30 & .799 & S. Agree & 3.94 & .858 & Agree \\
\hline $\begin{array}{l}\text { 7- Social distancing, masks, healthy eating is an essential part of } \\
\text { my travelling behavior that does not spoil my holiday enjoyment. }\end{array}$ & 1.92 & .842 & Disagree & 3.08 & 1.459 & \multicolumn{2}{|c|}{ Maybe } \\
\hline
\end{tabular}


Saudi Tourists' traveling preferences, habits and intentions before and after covid-19 pandemic

According to Table 4 displayed results, Saudi travelers' travel behavior, preferences and habits have changed after covid-19 pandemic and the travel restrictions posed due to its' wide spread. Their acceptance level concerning travelling in groups, visiting crowded places, and using digital channels in holiday planning and booking decreased after the pandemic than before, while the majority still prefer international trips over domestic ones. As they prefer more after the pandemic to travel by private cars than planes and public transportation modes, also nowadays health and safety have the first priority concern before price, accessibility and service quality, as social distancing, masks, healthy eating became an essential part of their travelling behavior that does not spoil holiday enjoyment.

Table 4. T - Test

Paired Samples Correlations

\begin{tabular}{|c|c|c|c|c|}
\hline \multicolumn{2}{|c|}{} & $\mathrm{N}$ & Correlation & Sig. \\
\hline $\begin{array}{c}\text { Pair } \\
1\end{array}$ & $\begin{array}{c}\text { after \& } \\
\text { before }\end{array}$ & 374 & .964 & .000 \\
\hline
\end{tabular}

Table 5. Paired Samples Test

\begin{tabular}{|c|c|c|c|c|c|c|c|}
\hline & \multicolumn{4}{|c|}{ Paired Differences } & $\mathrm{t}$ & $\mathrm{df}$ & Sig. (2-tailed) \\
\hline & \multirow[t]{2}{*}{ Mean } & \multirow{2}{*}{$\begin{array}{c}\text { Std. } \\
\text { Deviation }\end{array}$} & \multicolumn{2}{|c|}{$\begin{array}{c}\text { 95\% Confidence } \\
\text { Interval of the Difference }\end{array}$} & & & \\
\hline & & & Lower & Upper & & & \\
\hline after - before & .38503 & .28333 & .35622 & .41384 & 26.280 & 373 & .000 \\
\hline
\end{tabular}

\section{T-Test to examine the effect of Covid-19 travel restrictions on travelers' habits, preferences and intentions}

Paired simple t-.test has been conducted with sentences displayed in Table 4 about travelers' habits before and after covid-19. Table 5 shows that there is a strong statistical relationship between the two variables (sig=0.000). Table 6 shows that $\mathrm{P}$. value $=(26.280)$ and is significant at 0.000 (less than 0.05$)$ which indicates that there is a difference between the variables, meaning that Covid-19 caused changes in tourists' travel behavior, habits, preferences and intentions.

\section{RESULTS AND DISCUSSION}

According to the results of the study, Saudi travelers' travel intentions and preferences differ according to their ages, the majority preferred to travel accompanied by family to regional destinations in comparison to whom preferred to travel to international long distance destinations, which is opposite to what they used to prefer before the pandemic, meaning that travel preferences, habits and intentions are affected by Covid-19 travel restrictions.

Saudi travelers' travel behavior, preferences and habits have changed after Covid-19 pandemic and the travel restrictions posed due to its' wide spread. Their acceptance level concerning travelling in groups, visiting crowded places, and using digital channels in holiday planning and booking decreased after the pandemic than before, while the majority still prefer international trips over domestic ones. As they prefer more after the pandemic to travel by private cars than planes and public transportation modes, also nowadays health and safety have the first priority concern before price, accessibility and service quality, as social distancing, masks, healthy eating became an essential part of their travelling behavior that does not spoil holiday enjoyment.

\section{CONCLUSION}

Easing and lifting of travel restrictions has become urgent to start tourism recovery from the negative social and economic effects of the pandemic, which requires full and rapid coordination between the world's governments. As well, tourism associations and establishments have to aware tourists to accept the new travel and tourism safety procedures, and convince them that it became an essential part of their travel experience, and without these procedures tourists are at great risk and will never enjoy their holiday trips. Tourist establishments should depend more widely on digital methods in providing their services, before, during and after the trip, to adopt with the new changes in tourists' preferences and accomplish their satisfaction. Airlines and other tourist transportation public modes must develop health safety procedures on board of their means of transportation, as well as in airports, land modes stations and marine ports to regains international tourist movement trust in international and regional travel, and accomplish full recovery of tourism industry.

\section{REFERENCES}

Adam, I. (2015). Backpackers' risk perceptions and risk reduction strategies in Ghana. Tourism Management, 49, 99-108. https://doi.org/10.1016/j.tourman.2015.02.016

Adams, T. (2014). Simon Anholt Interview, There is only one global superpower: public opinion, The Guardian newspaper, 3. https://www.theguardian.com/politics/2014/nov/30/simon-anholt-good country-party-global-superpower-public-opinion

AL-Feky, A. (2016). Saudis most preferred tourist destinations for 2016 summer vacation, Arab International Economic newspaper. www.aleqt.com/2016/05/30.

Ayeh, J. (2017). Travel trends in the Middle East. In The SAGE International Encyclopedia of Travel and Tourism, 1349-1353, SAGE Publications Inc. http://dx.doi.org/10.4135/9781483368924.n484

Bakar, N., \& Rosbi, S. (2020). Effect of coronavirus disease (COVID-19) to tourism industry. International Journal of Advanced Engineering Research and Science, 7(4), 189 - 193. https://doi.org/10.22161/ijaers.74.23

Budiasa, M., \& Nadra, N. (2016). The potential cost of travel restriction on tourism industry. Asia Tourism Forum 2016 - The 12 th Biennial Conference of Hospitality and Tourism Industry in Asia (ATF-16), Research Gate. https://doi.org/10.2991/atf-16.2016.79

Camitz, M., \& Liljeros, F. (2006). The effect of travel restrictions on the spread of a moderately contagious disease, BMC Medicine, 4 (32) 1-10. https://doi.org/10.1186/1741-7015-4-32

Cui, F., Liu, Y., Chang, Y., Duan, J., \& Li, J. (2016). An overview of tourism risk perception, Natural Hazards, 82 (1) $643-658$. https://doi.org/10.1007/s11069-016-2208-1

Deb, S., \& Nafi, S. (2020). Impact of covid-19 pandemic on tourism: recovery proposal for future tourism. Geo Journal of Tourism and GeoCities, 33(4spl), 1486-1492. https://doi.org/10.30892/gtg.334spl06-597 
Deloitte (2020). COVID-19 global mobility update, (5.6. 2020), UK. https://www2.deloitte.com/content/dam/Deloitte/ch/Documents/ tax/deloitte-ch-covid-19-global-mobilityupdate- 02-05-June-2020.pdf

Elias, B. (2020). Addressing covid-19 pandemic impacts on civil aviation operations, R46483, CRS Report (2), (17.8. 2020), Congressional Research Service, USA.

Gallo, P., Matušíková, D., Šenková, A., Šambronská, K., \& Molčák, T. (2021). Crisis and recovery of business entities in tourism in the post pandemic period in Slovakia, GeoJournal of Tourism and Geosites, 38(4), 1033-1041. https://doi.org/10.30892/gtg.38407-741

Haque, A. (2020). Covid-19 and changes in travel behavior: is there any 'New Normal'? Research Gate, June 2020. https://www.researchgate.net/publication/342437359

Jamal, T., \& Budke, C. (2020). Tourism in a world with pandemics: local-global responsibility and action. Journal of Tourism Futures, 6(2) 181-188. https://doi.org/10.1108/JTF-02-2020-0014

Kampel, K. (2020). Covid-19 and tourism: charting a sustainable, resilient recovery for small states, a special focus on covid-19 and the Commonwealth, ISSUE 163, 1-14. Geneva, Switzerland.

Kumudumali, S. (2020). Impact of covid-19 on tourism industry: A review, MPRA Munich Personal RePEc Archive, MPRA Paper No. 102834. https://mpra.ub.uni-muenchen.de/102834/

Matiza, T., \& Slabbert, E. (2021). Tourism is too dangerous, perceived risk and the subjective safety of tourism activity in the era of covid-19, Geo Journal of Tourism and Geosites, 36(2spl), 580-588. https://doi.org/10.30892/gtg.362spl04-686

Matiza, T. (2020). Post- covid-19 crisis travel behavior: towards mitigating the effects of perceived risk, Journal of Tourism Futures, Emerald Publishing Limited, ISSN 2055-5911. https://doi.org/10.1108/JTF-04-2020-0063

Niestad, M. (2020). Covid-19: EU support for the tourism industry, EPRS European Parliamentary Research Service, PE 649.368. https://www.europarl.europa.eu/news/en/headlines/society/20200429STO78175/covid-19-eu-support-for-the-tourismindustry

Orlik, T. Rush, J., Cousin, M., \& Hong, J. (2020). Coronavirus could cost the global economy \$2.7 trillion, here's how, Bloomberg Economics. https://www.bloomberg.com/graphics/2020-coronavirus-pandemic-global-economic-risk/

Petersen, E., McCloskey, B., Hui, D., Kock, R., Ntoumi, F., Memish, Z., Kapata, N., Azhar, E., Pollack, M., Madoff, L., Hamer, D., Nachega, J., Pshenichnaya, N., \& Zumla, A. (2020). Covid-19 travel restrictions and the international health regulations - call for an open debate on easing of travel restrictions, International Journal of Infectious Diseases IJID, vol. 94, 88-90. https://doi.org/doi:10.1016/j.ijid.2020.04.029

Puttaiah, M. (2020). All change: how covid-19 is transforming consumer behavior, Swiss Re Institute \& Evangelos Avramakis, Head Digital Ecosystems R\&D. https://www.swissre.com/institute/research/topics-and-risk-dialogues/health-and-longevity/covid-19-andconsumer-behaviour.html

Quilty, B., Diamond, C., Liu, Y., Gibbs, H., Russell, T., Jarvis, C., Prem, K., Pearson, C., Clifford, S., Flasche, S., Klepac, P., Eggo, R., \& Jit, M. (2020). The effect of travel restrictions on the geographical spread of covid-19 between large cities in China: a modeling study, BMC Medicine, 18, 259. https://doi.org/10.1186/s12916-020-01712-9

Rooley, J. (2020). How covid-19 has affected the aviation industry and its approach to risk, Willis Towers Watson Logo, Leading global advisory, broking and Solutions Company. https://www.willistowerswatson.com/en-GB/Insights/2020/06/how-covid-19-has-affected-the-aviation-industry

Sanchez, P., Voltes-Dorta, A., \& Cugueró-Escofet, N. (2020). An early assessment of the impact of covid-19 on air transport: just another crisis or the end of aviation as we know it? Research Gate, Journal of Transport Geography 86, 102749. https://doi.org/10.1016/j.jtrangeo.2020.102749 https://www.researchgate.net/publication/341905801

Seyfia, S., Hall, M., \& Shabanif, B. (2020). Covid-19 and international travel restrictions: the geopolitics of health and tourism, Tourism Geographies, An International Journal of Tourism Space, Place and Environment, 1-17, Routledge. https://doi.org/ $10.1080 / 14616688.2020 .1833972$

Sheard, N. (2014). Airports and urban sectorial employment, Journal of Urban Economics, 80,133-152. https://doi.org/10.1016/j.jue.2014.01.002

Shi, K., De Vos, J., Yang, Y., \& Witlox, F. (2019). Does e-shopping replace shopping trips?, Transportation Research Part A: Policy and Practice, Elsevier, 122(C), 21-33. https://doi.org/10.1016/j.tra.2019.01.027

Sultana, S., Islam, T., \& Islam, M. (2020). Impact of covid-19 pandemic on top tourist destinations in the world. Journal of Tourism, Hospitality and Sports, Research Gate, 50, 41-50. https://doi.org/10.7176/JTHS/50-07

Wolff, K., Larsena, S., \& Ogaard, T. (2019). How to define and measure risk perceptions. Annals of Tourism Research, $79,10275$.

*** Alarabiya net (2021). Saudi Arabia starts today to permit citizens to travel abroad, E-article, 20.5.2021. https://www.alarabiya.net

*** Picodi com Analyses Team (2019). Time to relax, Analytic Report. https://www.picodi.com/sa/bargain-hunting /time-to-relax

*** Centers for Disease Control and Prevention (2021). 1957-1958 Pandemic (H2N2 virus), 15.4.2021. https://www.cdc.gov/flu /pandemic-resources/1957-1958-pandemic.html

*** ICAO (2021). Effects of novel coronavirus (COVID19) on civil aviation: economic impact analysis Montréal, Economic Development Air Transport Bureau. (27.01.2021), Canada.

*** OECD (2020). Covid-19 and the aviation industry: impact and policy responses, tackling coronavirus browse OECD contributions. (15.10.2020), 1-8.

*** Saudi Ministry of Interior (2021). Statistics of Saudis travelling in the first two days of the official permit for citizens to travel. https://www.alarabiya.net 20 may 2021

***UNWTO (2021). A compilation of data on outbound tourism by country. UNWTO Tourism Dashboard Country profiles. outbound tourism. https://www.unwto.org/country-profile-outbound-tourism

*** UNWTO (2020). Compendium of tourism statistics and data files, UNWTO year book of tourism statistics, 25.5.2021. https://www.data.worldbank.org

*** UNWTO (2020). World Tourism Barometer, Special focus on the impact of covid-19, Madrid, UNWTO.

*** UNWTO (2020). COVID - 19 related travel restrictions a global review for tourism, Seventh Report (10.9.2020).

*** UNWTO Sustainable Development of Tourism Department.

*** UNWTO (2020). COVID - 19 related travel restrictions a global review for tourism, Eighth Report (2.12. 2020).

*** UNWTO Sustainable Development of Tourism Department.

*** World Health Organization (WHO) (2020). Coronavirus disease (COVID-19) pandemic. https://www.who.int/emergencies/ diseases/novel-coronavirus-2019

Article history: Received: 16.08.2021 Revised: 06.11.2021 Accepted: 28.12.2021 Available online: 17.01.2022 